\title{
Efek variasi suhu dan waktu blanching pada kualitas manisan nangka kering (Artocarpus heterophyllus)
}

\section{Effect of variations in temperature and blanching time on the quality of candied dried jackfruit (Artocarpus heterophyllus)}

\author{
Lorine Tantalu $^{1{ }^{*}}$, Sri Handayani ${ }^{1}$, Rozana $^{1)}$, Ferianus Wunga ${ }^{1)}$ \\ ${ }^{1}$ Program Studi Teknologi Industri Pertanian, Universitas Tribhuwana Tunggadewi Malang \\ *Email: lorinetantalu@gmail.com
}

Diterima: 03/02/2020; ditinjau: 04/02/2020; disetujui: 15/03/2020

\begin{abstract}
The aim of this study was to obtain a combination of blanching temperature and time in making candied jackfruit. Randomized factorial was used as research design within two factors, namely blanching temperature $\left(80^{\circ} \mathrm{C}, 85^{\circ} \mathrm{C}\right.$, and $\left.90^{\circ} \mathrm{C}\right)$ and blanching time (2, 3 , and 4 minutes). The quality test of candied dried jackfruit includes organoleptic test of the hedonic scale scoring method namely taste, color, aroma, and texture. Chemical tests include water content, sugar content, and yield. The best treatment is a combination of $90^{\circ} \mathrm{C}$ blanching temperature and 4 minutes blanching time, which produces a product with a water content of $40.91 \%$, a sugar content of $73.72 \%$, even for yield raised up to $35.51 \%$. Taste, color, aroma, and texture parameters did not show any real effect. Based on the results of the business feasibility analysis, it is found that the processing of the candied jackfruit processing industry is feasible to be cultivated on a small industrial scale.
\end{abstract}

Keywords: candied jackfruit, blanching temperature, blanching time.

\begin{abstract}
ABSTRAK
Tujuan penelitian ini untuk mendapatkan kombinasi perlakuan suhu dan waktu blanching pada pembuatan manisan nangka. Penelitian ini menggunakan Rancangan Acak Lengkap (RAL) Faktorial Perlakuan terdiri atas dua faktor yaitu suhu blanching $\left(80^{\circ} \mathrm{C}, 85^{\circ} \mathrm{C}\right.$, dan $\left.90^{\circ} \mathrm{C}\right)$ dan waktu blanching (2, 3, dan 4 menit). Uji kualitas manisan nangka kering meliputi uji organoleptik metode hedonic scale scoring yaitu rasa, warna, aroma, dan tekstur. Uji kimia meliputi kadar air, kadar gula, serta rendemen. Perlakuan terbaik adalah kombinasi suhu blanching $90^{\circ} \mathrm{C}$ dan waktu blanching 4 menit, yang menghasilkan produk dengan kadar air $40,91 \%$, kadar gula $73,72 \%$, dan rendemen $35,51 \%$. Parameter rasa, warna, aroma, dan tekstur tidak menunjukkan pengaruh nyata. Berdasarkan hasil analisa kelayakan usaha didapatkan bahwa industri pengolahan manisan nangka layak diusahakan pada skala industri kecil.
\end{abstract}

Kata kunci : manisan nangka kering, waktu blanching, suhu blanching

\section{PENDAHULUAN}

Nangka menjadi salah satu komoditas Indonesia yang sangat melimpah ketika panen raya tiba. Ketika jumlah produksi Buah Nangka yang cukup tinggi tidak diimbangi dengan kegiatan konsumsi yang tinggi, mengakibatkan harga jual yang cukup rendah untuk mengurangi kerugian akibat pembusukan buah. Secara umum, daging Buah Nangka rata-rata yang ditemukan di Indonesia memiliki kadar air yang berkisar pada $86,6 \%$, nilai ini cukup tinggi untuk memicu pembusukan daging buah 
(Anggriana, Muhardi, dan Rostiati, 2017). Beberapa alternatif untuk mengolah Buah Nangka telah dilakukan, baik menjadi makanan ringan (jackfruit snack) berupa keripik nangka, minuman sari buah nangka, nangka kering (jackfruit leather) dan manisan nangka (Wijayanti et al., 2017; Amalia dan Susanto, 2017; Sohibulloh, Hidayati, dan Burhan, 2013).

Manisan adalah produk yang diolah dengan menambah gula, terdiri atas manisan basah dan kering yang berbeda cara pembuatan, daya awet dan penampakannya. Tujuan pemberian gula adalah untuk mengawetkan manisan, memberi rasa manis, dan mencegah tumbuhnya mikroorganisme (jamur kapang, dan bakteri), sehingga dapat memperpanjang daya simpan. Manisan kering memiliki daya simpan yang lebih lama dibandingkan dengan manisan buah basah (Rosyida dan Sulandri, 2014; Septya, Suhaidi, dan Ridwansyah, 2017). Hal ini disebabkan karena kadar air pada manisan buah kering lebih rendah dan kandungan gulanya lebih tinggi dibandingkan manisan buah basah. Difusi gula ke dalam bahan secara perlahan-lahan akan terjadi pada pengeringan dengan penambahan gula secara eksternal, sehingga air yang keluar dari bahan lebih sedikit dibandingkan dengan gula yang masuk (Praseptiangga et al., 2016; Sohibulloh, Hidayati, dan Burhan, 2013). Air yang tertahan pada buah akan mempertahankan tekstur dan menjadikan tekstur manisan buah kering tidak berbeda jauh saat tekstur buah dalam keadaan segar. Hal penting yang harus diupayakan adalah menjaga aroma, rasa dan warna agar tidak mengalami penurunan mutu pangan.

Pengolahan menggunakan suhu tinggi pada bahan baku yang mengandung glukosa umumnya menghasilkan produk yang berwarna kecokelatan. Perubahan warna ini sering tidak dikehendaki, khususnya untuk produk manisan buah kering. Proses pencokelat tersebut merupakan bagian dari reaksi browning non enzimatis akibat bereaksinya gugus karbonil dan gugus amina (Effendi, Surawan, dan Winarto, 2015). Proses yang dapat diaplikasikan untuk menonaktifkan gugus fungsional tersebut agar tidak terjadi browning adalah dengan melakukan blanching (Pujimulyani et al., 2010).

Blanching atau pemanasan pada suhu tertentu merupakan proses yang dapat diaplikasikan untuk mengurangi penurunan mutu gizi, maupun sifat fisik dan sensori bahan pangan khusus untuk penanganan pengeringan (Asgar dan Musaddad, 2008). Beberapa penelitian untuk mengurangi tingkat pencokelat pada produk pertanian telah dilakukan di antaranya untuk meningkatkan derajat putih tepung kimpul (Ayu dan Yuwono, 2014), tepung kopyor (Antu, Hasbullah, dan Ahmad, 2017), kunir putih (Pujimulyani et al., 2010) dan lobak putih (Asgar dan Musaddad, 2008) belum dilakukan pengeringan.

Tujuan penelitian ini adalah untuk mendapatkan suhu dan waktu blanching terhadap mutu manisan nangka kering. Hasil penelitian nantinya diharapkan dapat bermanfaat bagi pelaku industri makanan ringan dengan material utama berupa buah nangka untuk dapat meningkatkan nilai ekonomis penting ketika panen raya tiba, sekaligus sebagai bentuk upaya sediaan makanan dalam bentuk awetan manisan kering.

\section{METODE PELAKSANAAN}

\section{Bahan}

Bahan yang digunakan dalam penelitian ini di antaranya yaitu Buah Nangka segar, gula pasir, larutan kapur sirih dan aquades.

\section{Alat}

Beberapa peralatan yang digunakan dalam penelitian ini di antaranya peralatan perendaman, alat peniris, alat pemanas, dan oven pengering.

\section{Rancangan penelitian}

Penelitian ini menggunakan rancangan acak lengkap (RAL) dengan dua faktor yaitu faktor pertama adalah suhu blanching dengan 3 taraf yaitu $80^{\circ} \mathrm{C}, 85^{\circ} \mathrm{C}, 90^{\circ} \mathrm{C}$ Faktor kedua adalah waktu blanching 
dengan 3 taraf yaitu 2 menit, 3 menit, 4 menit. Masing-masing faktor dilakukan ulangan sebanyak 3 kali. Rancangan Acak Lengkap (RAL) tersebut, dengan ketentuan sebagai berikut.

Tabel 1. Rancangan percobaan

\begin{tabular}{llll}
\hline Faktor & P1 $=\mathbf{2}$, & P2 $=\mathbf{3}$, & P3 $=4$ \\
\hline L1 $=80^{\circ} \mathrm{C}$ & L1P1 & L1P2 & L1P3 \\
L2 $=85^{\circ} \mathrm{C}$ & L2P1 & L2P2 & L2P3 \\
L3 $=90^{\circ} \mathrm{C}$ & L3P1 & L3P2 & L3P3 \\
\hline Keterangan : (') )= menit & &
\end{tabular}

Pembuatan manisan Buah Nangka kering dimulai dengan memilih buah nangka dengan tingkat kematangan sedang dan segar sebanyak $5 \mathrm{~kg}$, kemudian dicuci sampai getah dan kotoran lainnya tidak menempel pada daging buah. Proses dilanjutkan dengan melakukan blanching pada suhu $80^{\circ} \mathrm{C}$, $85^{\circ} \mathrm{C}, 90^{\circ} \mathrm{C}$ dengan waktu blanching 2 menit, 3 menit, dan 4 menit pada masingmasing suhu sesuai rancangan penelitian. Selanjutnya, buah nangka tersebut direndam dalam larutan kapur sirih 2\% selama 6 jam untuk kemudian dicuci sampai tidak ada kapur yang masih menempel. Tahap selanjutnya yaitu daging buah nangka dibaluri dengan gula sebanyak 750 gr dalam 1 liter (75\%) untuk masing-masing perlakuan suhu dan waktu blanching selama 12 jam. Setelah dilakukan perendaman, dilanjutkan dengan proses pengeringan selama 24 jam pada suhu $60^{\circ} \mathrm{C}$.

Perendaman dengan kadar larutan gula pada konsentrasi $70-75 \%$ dari penelitian sebelumnya menunjukkan hasil yang paling disukai oleh panelis untuk rasa manisan buah kering (Anaya et al., 2018; Septya, Suhaidi, dan Ridwansyah, 2017). Perendaman gula berkonsentrasi tinggi ini ditujukan untuk menjaga keseimbangan pada proses masukan dan keluarnya air dari larutan gula ke dalam buah atau sebaliknya. Hasil yang diberikan dengan perendaman larutan gula ini akan menghasilkan tekstur manisan buah kering yang tetap pada kondisi awal buah namun kering sebagai efek dari difusi gula ke dalam bahan secara perlahan-lahan sehingga air yang keluar dari bahan lebih sedikit dibandingkan dengan gula yang masuk.
Parameter yang digunakan untuk mengetahui efektivitas suhu dan waktu blanching pada pembuatan manisan buah nangka kering ini meliputi kadar air, total gula (\%), rendemen(\%), serta organoleptik sesuai SNI 01-2891-1992.

\section{Analisis data}

Dari hasil parameter yang di uji, data tersebut dianalisis menggunakan ANOVA (Analisis of Variance) dilanjutkan dengan uji Duncan untuk mengetahui beda nyata antar perlakuan $5 \%$.

\section{HASIL DAN PEMBAHASAN}

\section{Kadar air}

Gambar 1 menunjukkan bahwa kadar air pada manisan nangka kering mempunyai nilai yang berpengaruh nyata $(\mathrm{P}<0,05)$. Tiap perlakuan menghasilkan nilai yang berbeda nyata.

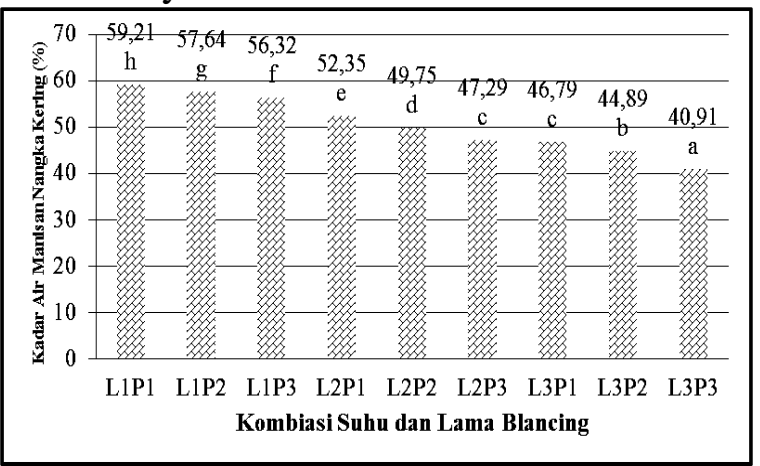

Gambar 1. Rata-rata kadar air manisan buah nangka kering masing-masing perlakuan.

Kadar air tertinggi manisan nangka kering sebesar 59,21\% diperoleh pada perlakuan L1P1 dengan suhu $80^{\circ} \mathrm{C}$ selama 2 menit. Pengurangan air pada manisan buah nangka kering terjadi karena dehidrasi osmosis akibat perendaman dalam larutan gula mengakibatkan pengeluaran sejumlah air dari buah-buahan (Ramya dan Jain, 2017; Sohibulloh et al., 2013). Makin tinggi tingkat perendaman dan makin pekatnya konsentrasi gula yang digunakan jumlah air yang keluar dari bahan juga semakin banyak (Septya, Suhaidi, dan Ridwansyah, 2017). Pengeluaran air dari buah nangka ini mengakibatkan penurunan kadar air. Selain itu, penurunan kadar air juga bisa 
disebabkan oleh proses pengeringan yang melibatkan panas yang mengakibatkan adanya penguapan air (Shabrina dan Susanto, 2017; Ramdani dan Tamam, 2015)

\section{Total gula}

Gambar 2 menunjukkan hasil analisis kadar gula pada manisan nangka kering menunjukkan berpengaruh nyata $(\mathrm{P}>0,05)$. Tiap perlakuan menunjukkan nilai yang berbeda nyata akibat perbedaan suhu dan waktu blanching sebelum perendaman menggunakan larutan gula $75 \%$, Kandungan gula tertinggi pada manisan nangka kering sebesar 73,72 diperoleh pada perlakuan L3P3 dengan suhu blanching $90^{\circ} \mathrm{C}$ selama 4 menit.

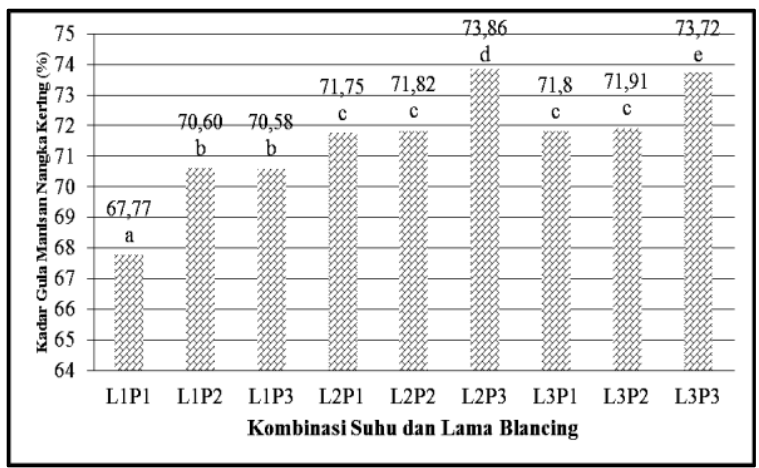

Gambar 2. Rata-rata total gula (\%) manisan nangka kering pada kombinasi perlakuan pengaruh suhu dan waktu blanching.

Hasil penelitian menunjukkan bahwa semakin tinggi suhu dan waktu blanching mampu meningkatkan total gula yang terkandung di dalam manisan buah nangka kering. Penelitian perbedaan dosis blanching sebelumnya menunjukkan bahwa semakin waktu blanching akan berakibat pada semakin tinggi total gula dalam produk pangan (Siregar, Rusmarilin, dan Limbong, 2015). Total gula yang dihasilkan juga cukup tinggi yaitu pada rentang 67,77 $73,72 \%$, dimana standar mutu manisan buah kering (SNI no. 0718-83) menyebutkan bahwa total gula minimum dalam persen $(\%)$ adalah pada nilai $40 \%$.

\section{Rendemen}

Gambar 3 menunjukkan bahwa proses blanching pada suhu $90^{\circ} \mathrm{C}$ selama 4 menit
(L3P3) menghasilkan rendemen terendah $(35,51 \%)$.

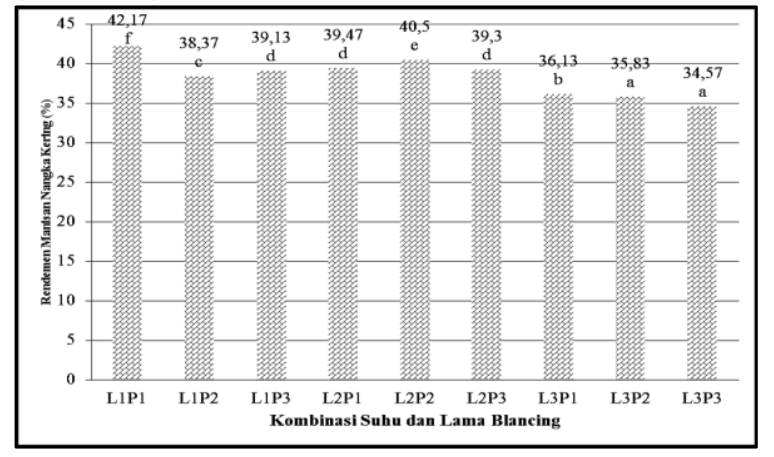

Gambar 3. rendemen manisan nangka kering (\%) pada suhu blanching dan waktu blanching.

Berdasarkan uji beda 5\% untuk mengetahui pengaruh perbedaan suhu dan waktu blanching pada suhu $80^{\circ} \mathrm{C}, 85^{\circ} \mathrm{C}$, $90^{\circ} \mathrm{C}$ masing-masing selama 2,3 dan 4 menit menunjukkan perbedaan nyata untuk perbedaan suhu blanching. Hal tersebut diduga berasal dari meningkatnya jumlah penguapan air yang berpengaruh pada menurunnya bobot bahan dengan semakin bertambahnya suhu dan waktu blanching. Suhu dan waktu blanching yang semakin tinggi akan berbanding lurus dengan konsentrasi penguapan air sehingga berimbas dengan semakin menurunnya rendemen (Asgar dan Musaddad, 2008)

\section{Uji organoleptik}

Hasil penelitian pengaruh suhu blanching dan waktu blanching terhadap tingkat kesukaan terhadap rasa, aroma, warna, tekstur manisan nangka kering tidak memberikan pengaruh nyata terhadap kesukaan akan rasa, aroma dan warna,demikian juga dengan waktu blanching tidak berpengaruh nyata terhadap warna manisan nangka kering (SNI 01-28911992).

\section{Rasa}

Gambar 4 menunjukkan bahwa Hasil uji organoleptik terhadap rasa tidak berpengaruh nyata $(\mathrm{P}>0,05)$. Hal ini selaras dengan kadar total gula yang cukup tinggi pada semua perlakuan manisan buah nangka kering. 


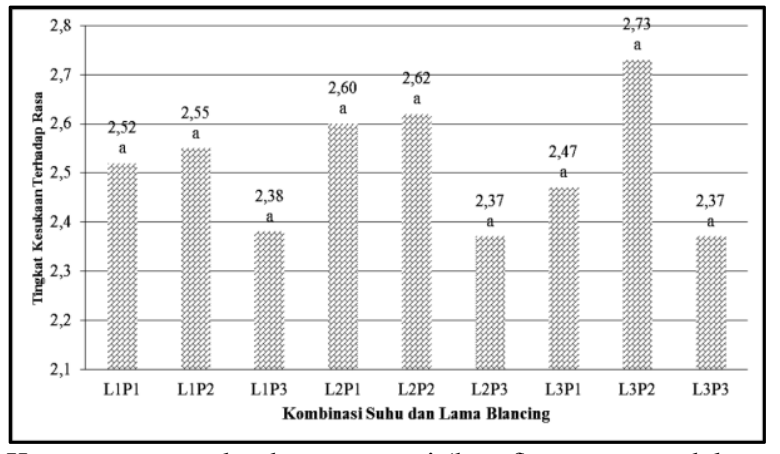

Keterangan : angka dengan notasi (huruf) yang sama dalam satu kolom menunjukkan tidak berbeda nyata menurut uji BNT taraf 5\%.

Gambar 4. Tingkat kesukaan terhadap rasa manisan nangka pengaruh suhu dan waktu blanching.

Tingkat kesukaan panelis terhadap rasa manisan buah nangka kering menunjukkan bahwa perlakuan blanching dan perendaman gula semakin memberikan rasa yang disukai untuk produk manisan kering. Kandungan gula yang cukup tinggi (75\%) pada proses perendaman menyebabkan tingginya glukosa dan fruktosa pada produk akibat aktivitas inverse sukrosa saat perendaman (Hu et al., 2016; Siregar, Rusmarilin, dan Limbong, 2015).

\section{Aroma}

Hasil uji organoleptik para panelis terhadap aroma menunjukkan perlakuan perbedaan suhu dan waktu blanching tidak berpengaruh nyata $(P>0,05)$ sehingga tiap perlakuan menghasilkan nilai tidak berbeda nyata.

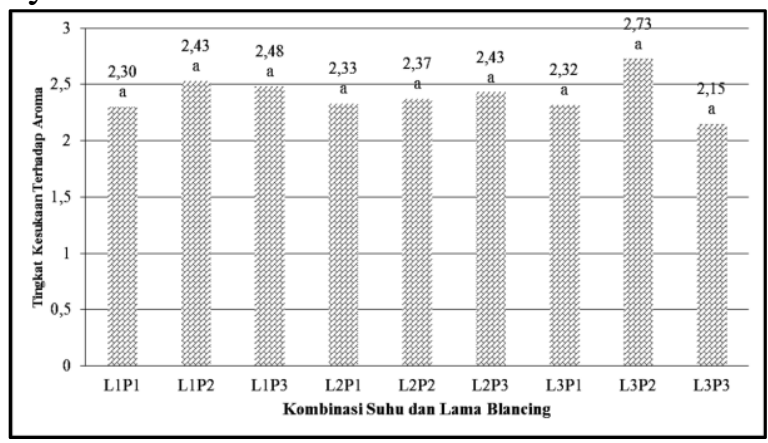

Keterangan : angka dengan notasi (huruf) yang sama dalam satu kolom menunjukkan tidak berbeda nyata menurut uji BNT taraf 5\%.

Gambar 5. Tingkat kesukaan terhadap aroma manisan nangka pengaruh suhu dan waktu blanching.

Rata-rata panelis cukup menyukai aroma manisan buah nangka kering dengan skor 2,15-2,73. Penurunan aroma nangka pada manisan buah nangka kering diduga diakibatkan oleh perlakuan suhu dan waktu blanching. Semakin meningkatnya suhu dan lama pemanasan akan meningkatkan laju difusi molekul dalam sel, , sehingga kemungkinan besar molekul air yang mengikat aroma nangka ikut terlarut (Sohibullo, Hidayati, dan Burhan, 2013)

\section{Warna}

Hasil uji organoleptik para panelis terhadap warna menunjukkan hasil yang tidak berpengaruh nyata $(\mathrm{P}<0,05)$. Tiap perlakuan tidak menunjukkan perbedaan nyata, karena dari perendaman larutan gula terlalu tinggi dapat mempertahankan warna sehingga tidak merusak jaringan daging buah nangka dimana terdapat pigmen atau zat warna di dalamnya.

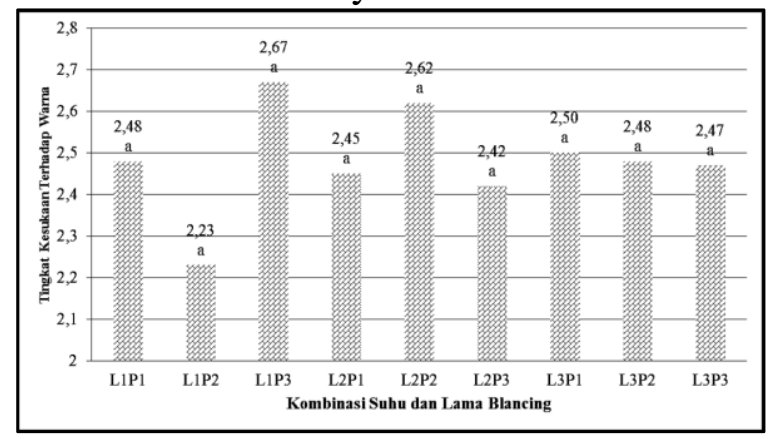

Keterangan : angka dengan notasi (huruf) yang sama dalam satu kolom menunjukkan tidak berbeda nyata menurut uji BNT taraf 5\%.

Gambar 6. Tingkat kesukaan terhadap warna manisan nangka pengaruh suhu dan waktu blanching.

Ada kecenderungan semakin tinggi konsentrasi gula, maka warna menjadi semakin gelap. Hal ini berasal dari proses browning non enzimatis yaitu karamelisasi glukosa oleh suhu tinggi (Winarno, 2004).

\section{Tekstur}

Hasil uji organoleptik para panelis terhadap tekstur menunjukkan hasil yang tidak berpengaruh nyata $(\mathrm{P}>0,05)$. Tiap perlakuan tidak menunjukkan nilai yang berbeda nyata, karena pada perlakuan konsentrasi suhu dan waktu blanching tidak memberikan pengaruh yang signifikan terhadap tekstur manisan nangka kering. 


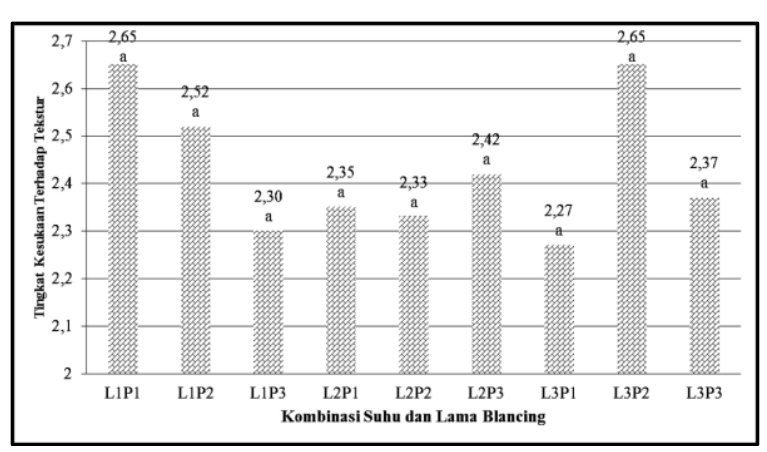

Keterangan : angka dengan notasi (huruf) yang sama dalam satu kolom menunjukkan tidak berbeda nyata menurut uji BNT taraf 5\%.

Gambar 7. Tingkat kesukaan terhadap tekstur manisan nangka pengaruh suhu dan waktu blanching

Analisa parameter tekstur untuk manisan buah nangka kering paling menunjukkan pula bahwa panelis cenderung cukup menyukai tekstur liat pada manisan buah kering. Liatnya manisan buah nangka tersebut diduga disebabkan oleh proses perendaman gula yang menggantikan posisi air pada daging buah (Gabrielsen et al., 2014). Kandungan gula tersebut memberikan struktur yang lebih kompak dan lekat pada daging buah tersebut. Tekstur sendiri dipengaruhi oleh adanya kandungan gula dalam produk manisan kering (Goswami et al., 2011). Semakin tinggi suhu dan lama pemanasan maka kadar total gula akan semakin meningkat, sehingga tekstur produk akan semakin liat dan keras (Shabrina dan Susanto, 2017).

\section{KESIMPULAN}

Berdasarkan penelitian dan pembahasan yang dilakukan dapat disimpulkan bahwa bahwa perlakuan L3P3 yaitu pada suhu blanching $90^{\circ} \mathrm{C}$ dengan waktu blanching 4 menit menghasilkan manisan nangka kering dengan karakteristik terbaik meliputi kadar air 40,91\%, total gula $73,72 \%$, yang didukung dengan penilaian organoleptik yang cukup tinggi, walaupun rendemen masih rendah $(35,51 \%)$. Hal ini dapat dijadikan rujukan dasar untuk memulai produksi manisan buah nangka kering pada industri kecil. Hal ini juga didukung adanya preferensi panelis yang baik ini menjadikan manisan nangka kering yang disimpulkan disukai panelis.

\section{UCAPAN TERIMA KASIH.}

Ucapan terima kasih disampaikan kepada Direktorat Jenderal RISTEKDIKTI atas pendanaan penelitian pada skim Pengabdian Kepada Masyarakat PKM tahun pendanaan 2018, sehingga dapat melibatkan mahasiswa dan menghasilkan jurnal penelitian.

\section{DAFTAR PUSTAKA}

Anaya, L. M., González, G. A., Domínguez, J. A., Olmos, J. E., Pérez, A., \& Montalvo, E. (2018). Effects of minimal processing technologies on jackfruit (Artocarpus heterophyllus Lam.) quality parameters. Food and Bioprocess Technology, 11(9), 17611774. https://doi.org/10.1007/s11947018-2136-Z

Anggriana, A., Muhardi, \& Rostiati. (2017). Karakteristik buah nangka (Artocarpus heterophyllus Lamk). Agrotekbis, 5(3), 278-283.

Antu, M. Y., Hasbullah, R., \& Ahmad, U. (2017). Dosis blansir untuk memperpanjang umur simpan daging buah kelapa kopyor. Jurnal Penelitian Pascapanen Pertanian, 13(2), 92-99.

Asgar, A \& Musaddad, D. (2008). Pengaruh media, suhu, dan lama blansing sebelum pengeringan terhadap mutu lobak kering. Jurnal Hortikultura, 18(1), 87-94.

Ayu, D. C., \& Yuwono, S. S. (2013). Pengaruh suhu blansing dan lama perendaman terhadap sifat fisik kimia tepung kimpul (Xanthosoma sagittifolium). Jurnal Pangan dan Agroindustri, 2(2), 110-120.

Amalia, K. D., \& Susanto, W. H. (2017). Pembuatan lempok nangka (Artocarpus heterophyllus) (kajian tingkat kematangan buah nangka bubur dan konsentrasi maizena terhadap karakteristik fisik, kimia, organoleptik). Jurnal Pangan dan Agroindustri, 5(3), 38-49. 
Effendi, Z., Electrika, F., Surawan, \& Winarto. (2015). Effect of blanching and drying methods on physicochemical properties of orange sweet potato flour (Ipomoea batatas L.). Jurnal Agroindustri, 5(2), 109-117.

Gabrielsen, M., Rahman, P.S.A., Othman, S., Hashim, O.H., \& Cogdell, R. J. (2014). Structures and binding specificity of galactose- and mannose- binding lectins from champedak: Differences from jackfruit lectins. Acta Crystallographica Section F: Structural Biology Communications, 70(6), 709-716. https://doi.org/10.1107/S2053230X140 08966

Goswami, C., Hossain, M. A., Kader, H. A., \& Islam, R. (2011). Assessment of physicochemical properties of jackfruits'(Artocarpus heterophyllus Lam) pulps. Journal of Horticulture, Forestry and Biotechnology, 15(3), 26-31.

Hu, L., Wu, G., Hao, C., Yu, H., \& Tan, L. (2016). Transcriptome and selected metabolite analyses reveal points of sugar metabolism in jackfruit (Artocarpus heterophyllus Lam.). Plant Science, 248, 45-56. https://doi.org/10.1016/j.plantsci.2016. 04.009

Praseptiangga, D., Aviany, T.P., Her, N., \& Parnanto, R. (2016). Pengaruh penambahan gum arab terhadap karakteristik fisikokimia dan sensoris fruit leather nangka (Artocarpus heterophyllus). Jurnal Teknologi Hasil Pertanian, 9(1), 71-83.

Pujimulyani, Raharjo, S., Marsono, Y. \& Santoso, U. (2010). Pengaruh blanching terhadap aktivitas antioksidan, kadar fenol, flavonoid, dan tanin terkondensasi kunir putih. Jurnal Agritech, 30(3), 141-147.

Ramya, V., \& Jain, N. K. (2017). A review on osmotic dehydration of fruits and vegetables: An integrated approach. Journal of Food Process Engineering, 40(3), $1-22$. https://doi.org/10.1111/jfpe.12440
Rosyida, F., \& Sulandri, L. (2014). Pengaruh jumlah gula dan asam sitrat terhadap sifat organoleptik , kadar air dan jumlah mikroba manisan kering siwalan (Borassus flabellifer). $E$ Journal Boga, 3(1), 297-307.

Septya, D., Suhaidi, I., \& Ridwansyah. (2017). Pengaruh konsentrasi gula dan lama penyimpanan terhadap mutu manisan basah batang daun pepaya. Jurnal Rekayasa Pangan dan Pertanian, 5(1), 73-80.

Shabrina, Z.U., \& Susanto, W.H. (2017). Pengaruh suhu dan lama pengeringan dengan metode cabinet dryer terhadap karakteristik manisan kering apel vaerietas anna (Malus domestica b.). Jurnal Pangan dan Agroindustri, 5(3), 60-71.

Siregar, E. A., Rusmarilin, H., \& Limbong, L. N. (2015). The effect of blanching time and amount of sugar on quality of chinese mustard wet candy. Jurnal Rekayasa Pangan dan Pertanian, 3(2), 212-216.

Sohibulloh, I., Hidayati, D., \& Burhan. (2013). Karakteristik manisan nangka kering dengan perendaman gula bertingkat. Agrointek, 7(2), 84-89.

Ramdani, H., \& Tamam, B. (2018). Optimasi suhu dan waktu pada proses pengeringan manisan cabai merah (Capsicum annuum L.) menggunakan tunnel dehydrator comm. Horticulturae Journal, 2(2), 17-21.

Wijayanti, R. A. I. Y., Susanto, W. H., \& Wijayanti, N. (2018). Pengaruh tingkat kematangan buah nangka bubur (Artocarpus heterophyllus) dan proporsi gula terhadap karakteristik fisik, kimia, dan organoleptik lempok nangka bubur. Jurnal Pangan dan Agroindustri, 5(4), 20-30.

Winarno, F. G. (2004). Kimia pangan dan gizi. Jakarta : Gramedia. 